\title{
MITOS MASYARAKAT JAWA DALAM NOVEL CENTHINI: 40 MALAM MENGINTIP SANG PENGANTIN (KAJIAN ANTROPOLOGI SASTRA)
}

\author{
Kiki Astrea \\ Universitas Islam Darul Ulum Lamongan \\ boavidies@yahoo.com.085646844141.
}

\begin{abstract}
Abstrak: Antropologi sastra merupakan studi mengenai karya sastra dengan relevansi manusia. Dalam hal ini antropologi membahas mitos yang berkembang dalam diri manusia.Mitos merupakan suatu cerita yang sejenis dengan dongeng. Analisis mitos dalam novel Centhini:40 malam mengintip sang pengantin mencoba menemukan mitos yang berkembang di dalam tubuh masyarakat Jawa. Seperti mitos pernikahan, membangun rumah sampai mitos yang berhubungan dengan agama. Hasil analisis data memiliki makna mitos yang sesuai dengan antropologi sastra. Salah satu contoh analisis data, yaitu mitos nasib manusia ditentukan berdasarkan keturunan, bermakna bahwa nasib seseorang sesuai dengan keturunan, jika orang tuanya adalah raja maka dia nakan menjadi raja, jika orang tuanya adalah budak maka dia akan menjadi budak.
\end{abstract}

Kata kunci: mitos, masyarakat Jawa, Centini

\begin{abstract}
Literary anthropology is the study of literature with human relevance.In this case anthropology discusses the myths that developed in human beings.Myth is a similar story with a fairy tale.Analysis of myths in the novel Centhini: 40 nights trying to find a peek at the bride myths that developed in the body of the Java community.Like the myth of the marriage, building a house until the myths associated with religion.The analysis of data has a corresponding meaning to the myth of literary anthropology.One conth data analysis, namely the myth of human destiny is determined by heredity, meaning that the fate of a person in accordance with the offspring, if the parents are kings and will he became king, if his parents were slaves then he will be a slave.
\end{abstract}

Keyword: mythe, Java community, Centini

\section{PENDAHULUAN}

Mitos adalah cerita rakyat yang termasuk foklor lisan dan penyebarannya dari mulut ke telinga ke mulut, berupa pesta-pesta rakyat, upacara-upacara, adat kebiasaan ataupun takhayul.Sampai saat ini hampir seluruh masyarakat Jawa mengenal hal-hal tersebut dan masih melaksanakan kegiatan-kegiatan itu, ada yang melaksanakan karena sudah tradisi ada pula yang melaksanakan karena mengetahui arti dari adat tersebut (Hutomo, 1991:8).

Baik mitos maupun mite, sebagai ilmu pengetahuan yang disebut mitologi (Ratna, 2011:210). Batasan mitologi 
sebagai pengetahuan mengenai dunia mite atau tokoh-tokoh mite, seperti mitologi jawa, mitologi india, mitologi yunani.

Selanjutnya, mite dikatakan sebagai cerita asal-usul dan cerita dewa-dewa yang dapat diyakini sebagai sesuatu yang benar (Zaidan, 1997:17). Mite sebagai sebuah dongeng yang berisi cerita dewadewi telah diteliti sebagai salah satu karya seni yang dianggap nyata dan benar-benar pernah terjadi dalam dunia, walaupun sebenarnya mite merupaan khayalan manusia.

Pemilihan kajian mitos, karena mitos merupakan mitologi Jawa yang dianggap tabu da tidak benar, namun seiring berjalannya waktu mitos dianggap sejenis kebenaran. Artinya mitos tidak selamanya suatu kebohongan. Kebenaran itu dilakukan dengan cara ritual-ritual yang dilakukan masyarakat Jawa. Demikian juga pemilihan masyarakat Jawa sebagai subjek mitos, karena mitos lebih dikenal oleh masyarakat Jawa.

Masyarakat Jawa dikenal masih kental dengan adat-istiadat. Adat-istiadat masih dilestarikan oleh masyarakat Jawa, karena mereka masih sangat kental akan budaya warisan nenek moyang, novel Centhini:40 Malam Mengintip sang Pengantin termasuk karya yang banyak menggambarkan mitos Jawa. Novel ini bercerita tentang masyarakat Jawa dengan pembagian golongan. Masyarakat Jawa dipilih sebagai objek penelitian karena terdapat mitos-mitos yang menarik, yang berhubungan dengan kebudayaan Jawa yang berasal dari nenek moyang. Bukan karena masyarakat Jawa kental akan budaya dan mitos. Kerna mitos bukanlah suatu fenomena yang berkenaa dengan budaya saja, tetapi juga berhubungan dengan hukum, sosial, ilmiah dan alamiah yang terbentuk dari hubungan masyarakat dan kebiasaan yang tanpa disadarinya membentuk mitos. Mitos yang terjadi karena budaya terdapat dalam novel Centhini:40 Malam Mengintip Sang Pengatin.

\section{METODE}

Penelitianini berupa kualitatif yang tidak menggunakan hitungan angka atau rumus statistik. Penelitian ini menggunakan kajian antropolgi sastra dengan teori strukturalisme Levi-Strauss dan teori mitos, metode analisis deskriptif analitik dan strukturalis hermeneutik secara kualitatif, dengan teknik analisis menguraikan, mengklasifikaskan, dan menabelkan.

Sumber data penelitian ini adalah novel Centhini:40 Malam Mengintip Sang Pengantin karya Sunardian Wirodono. Metode pengumpulan data yang digunakan dalam penelitian ini adalah pertama dengan menentukan objek data dalam novel. Kedua yang dilakukan dalam mengumpulkan data, yaitu dengan identifikasi. Selanjutnya menyeleksi data yang telah digaris bawahi yang dianggap lebih relevan. Terakhir yang harus dilakukan dalam mengumpulkan data adalah dengan mengklasifikasikan data yang dikumpulkan dalam bentuk kalimat atau paragraf untuk kemudian dilakukan analisis deskriptif analitik dan hermeneutika dengan interpretasi peneliti.

\section{HASIL PENELITIAN}

Amongraga sebagai "priyayi kaya" dan "santri", Tambangraras "priyayi kaya" dan "santri", dan satu yang berbeda, yaitu Centhini "priyayi miskin" dan "santri". Berikut dalah "sejarah kehidupan" tokoh Amongraga,

Novel (CMMSP) adalah karya sastra yang banyak menggambarkan mitos budaya Jawa baik dalam bentuk 
tindakan maupun ucapan yang sering muncul dalam kehidupan masyarakat Jawa. Sesuai dengan kebudayaan Jawa yang masih mengikuti nilai-nilai, adatistiadat dan norma-norma kemasyarakatan seperti, makanan, ceritacerita, permainan dan acara.

Mitos masyarakat Jawa merupakan hal yang dijadikan pedoman kehidupan mereka, mitos-mitos tersebut memiliki makna yang dipercaya kebenarannya oleh pelaku mitos. Seperti halnya karya sastra lainnya, mitos dalam kajian antropologi sastra juga merupakan karya sastra yang harus diapresiasi dan dicari serta diketahui maknanya. Karena sebuah karya sastra merupakan hasil tangan manusia kreatif untuk diri sendiri maupun orang lain yang dibentuk berdasarkan inspirasi. Inspirasi itulah yang merupakan makna karya sastra yang diciptakan oleh manusia.

Nasib manusia ditentukan berdasarkan keturunan.Misalnya jika orang tuanya seorang raja maka putrinya akan menjadi puteri.Orang tuanya seorang pembantu maka putrinya akan menjadi pembantu.

Makna sebenarnya bahwa nasib sesuai dengan keturunan memang benar adanya, namun semua itu tergantung pada masing-masing individu. Jika anak raja dan kerajaannya hancur, maka pasti dia akan menjadi rakyat biasa walaupun kerajaan itu dihancurkan olehnya ataupun oleh orang lain. Sebaliknya, jika putri pembantu memiliki kegigihan yang kuat dalam mengejar cita-cita, maka dia bisa menjadi ratu dunia dengan usahanya melawan nasib dari orang tuanya. Karena nasib seseorang tidak akan berubah kecuali dia sendiri yang merubahnya.

Pandangan hidup masyarakat Jawa terhadap mitos-mitos Jawa tidak dapat dipisahkan dari kehidupan bermasyarakat. Mitos dijadikan landasan dan pedoman kehidupan masyarakat Jawa.Setiap kegiatan mereka tidak lepas dari mitos yang melekat dalam diri manusia. Seperti Nasib manusia ditentukan berdasarkan keturunan. Misalnya, jika orang tuanya adalah seorang raja, maka putrinya akan menjadi seorang putri. Dan, jika orang tuanya seorang pembantu, maka putrinya akan menjadi pembantu.Mitos ini tidak dianggap sebagai sebuah mitos belaka, melainkan sudah menjadi kebenaran bagi masyarakat jawa.

Perempuan yang sudah cukup umur tetapi pemilih, akan menjadi perawan tua.Pengantin baru harus dijaga sampai 40 malam.Bulan maulid adalah bulan yang baik untuk malaksanakan hajatanUpacara unduh pengantin dilakukan sampai sebelum sepasaran pernikahan dan dihiasi janur kuning, gamelan, makanan, shalawatan, dan jodangan.Ritual-ritual tersebut dilakkukan masyarakat Jawa dengan penuh perhitungan matang, setiap acara bagi mereka ada ritual-ritual tertentu untuk keberkahan hidup.

Memakan makanan, meminum minuman bekas orang yang berilmu tinggi dan berjabat tangan dengannya akan mendapat keberkahan dan rizki yang berlimpah.Rumah baru pengantin baru sebelum ditinggali harus ditutupi dengan kain berwarna putih.Syekh Amongraga (orang yang berilmu tinggi) setelah datang ke desa Wanamarta, desa ini menjadi hidup, tidak ada orang yang berjudi dan suara adzan terdengar bersahut-sahutan di setiap masjid.Mitos kelahiran dan kematian.

Mitos-mitos tersebut menjadi landasan hidup Masyarakat Jawa, setiap ritual dilaksanakan dengan penuh kepercayaan dan keikhlasan, bahwa orang yang memiliki kedudukan tinggi dalam suatu masyarakat, mereka yang 
diagungkan dan dimuliakan. Warga akan berbondong-bondong mendatangi orang yang dimuliakan dalam desa hanya untuk melihat, memeriahkan bahkan mencari rejeki dan barokah dari mereka yang berilmu tinggi, karena orang yang dimuliakan pastilah orang yang berilmu tinggi dan alim.

Kelahiran adalah awal kehidupan manusia. Dalam masyarakat Jawa, kelahiran seorang anak akan dirayakan dengan meriah. Ritual-ritual kelahiran dilakukan, dengan menyajikan aneka makanan serta doa yang diharapkan akan memberi kesehatan, kebahagiaan, kemuliaan dan keberkahan bagi manusia baru. Sedangkan kematian bukanlah akhir dari hidup, melainkan awal dari kehidupan kekal dengan mempertanggungjawabkan amal yang dilakukan ketika dia hidup.

\section{LANDASAN TEORI}

Antropologi sastra adalah analisis dan pemahaman terhadap karya sastra dalam kaitannya dengan kebudayaan. Dalam perkembangan berikut definisi tersebut dilanjutkan dengan pemahaman dalam perspektif kebudayaan yang lebih luas. Perkembangan yang dimaksudkan juga mengikuti perkembangan sosiologi sastra yang semula hanya berkaitan dengan masyarakat yang ada dalam karya sastra kemudian meluas pada masyarakat sebagai latar belakang penciptaan sekaligus penerimaan. Karya sastra dengan demikian bukan refleksi, bukan semata-mata memantulkan kenyataan, melainkan merefraksikan, membelokkannya sehingga berhasil mengevokasi keberagaman budaya secara lebih bermakna. Dalam hubungan ini akan terjadi proses timbal balik, keseimbangan yang dinamis antara kekuatan aspek sastra dengan antropologi itu sendiri. Bahkan, dalam analisis yang baik, seolah-olah tidak bisa dikenali lagi apakah yang dibicarakan termasuk sastra atau antropologi (Ratna, 2011:31).

Herman (dalam Rohmadi, 2011:23) Budaya dalam sastra jawa adalah budaya dan sastra yang sudah berusia sangat tua dan memiliki nilai-nilai luhur dan nilainilai abadi.Adat-istiadat masyarakat dan sopan santun pergaulan juga merupakan nilai tinggi yang sudah teruji oleh zaman.Adat-adat tersebut sudah diabadikan dalam tembang-tembang, tarian-tarian, dolanan dan kitab-kitab lama yang tinggi nilai budayanya.

Kebudayaan berarti keseluruhan tindakan manusia dalam kehidupan baik yang secara naluri, refleks dan tindakan alamiah yang dimilikinya secara dasar adalah suatu kebudayaan yang dilakukan dengan sopan santun dan sesuai dengan nilai-nilai agama, kitab-kitab, adat-adat dan budi luhur manusia.

Heddy (2012:181) istilah mitos, mite atau dongeng biasanya mengingatkan kita pada suatu kisah atau ceritera yang aneh, janggal atau lucu, dan umumnya sulit dimengerti maknanya, tidak dapat diterima kebenarannya, atau tidak perlu ditanggapi secara serius isinya. Kisah tersebut umumnya dianggap sebagai hasil khayalan iseng saja, karena isinya kebanyakan tidak sesuai dengan kenyataan sehari-hari.

Meskipun demikian, karena sifatnya ini pula mitos seringkali dipandang sebagai suatu yang suci, wingit atau bertuah dan tidak semua orang dapat dan boleh mengetahuinya.Mitos ini kemudian dapat juga digunakan sebagai alat kebenaran atau sumber kebenaran dari suatu peristiwa atau kejadian tertentu, dan menjadi alat legitimasi kekuasaan pihakpihak tertentu. 


\section{PEMBAHASAN}

Budaya Jawa mengenal struktur dalam masyarakat, yaitu priyayi, satri dan abangan. Dua dari tiga struktur tersebut terdapat pada tokoh-tokoh dalam Centhini, Amongraga dan Tambangraras. Amongraga dan Tambangraras tokoh tersebut termasuk dalam masyarakat priyayi kaya dan santri. Sedangkan Centhini termasuk priyayi miskin dan santri. Amongraga dan priyayi kaya dan santri, karena dia berasal dari keluarga kesunanan giri Surabaya, namun kesunanannya telah runtuh karena serangan Mataram sehingga Amongraga beserta dua saudaranya melarikan diri dan berpisah di perjalanan. Amongraga akhirnya terdampar di Wanamarta, dia ditawari oleh gurunya untuk menikah dengan putri pembesar Wanamarta. Akhirnya Amongraga memutuskan untuk menikah dengan Tambangraras demi mencapai tujuan untuk mencari kedua adiknya yang menghilang dan sembunyi dari kejaran Mataram.

"dan sekarang, Mataram hendak kita biarkan menyerang! Tidak!” Sunan Giri berkata lantang," "kita akan pertahankan sampai titik darah penghabisan".

Jayengresmi dan dua adiknya sama sekali tak bisa membantah. Akan sia-sia saja sekalipun sama sekali tidak menyetujui, tidak ada kata lain selain menurut pada perintah orang tua. Menmeprtahankan Giri.

Tambangraras adalah priyayi kaya, karena dia adalah putri orang terpandang di Wanamarta. Dia dipaksa agar segera menikah, tetapi dia hanya akan menerima pinangan dari pria yang mampu melindunginya di dunia dan di akhirat. Tambangraras termasuk santri, karena ayahnya adalah seorang kyai yang memiliki pesantren dan setiap hari mendapatkan siraman rohani.

"Kenapa Tambangraras belum kawin?" Jamal bertanya pada Ki Nuripin

"ooow, Tambangraras hanya mau kawin dengan lelaki yang cerdas, sudah banyak lelaki dari mana-mana melamarnya. Dari yang tampan kaya, maupun jelek kaya..."(2011:41)

Mitos masyarakat Jawa merupakan hal yang dijadikan pedoman kehidupan mereka, mitos-mitos tersebut memiliki makna yang dipercaya kebenarannya oleh pelaku mitos. Seperti halnya karya sastra lainnya, mitos dalam kajian antropologi sastra juga merupakan karya sastra yang harus diapresiasi dan dicari serta diketahui maknanya. Karena sebuah karya sastra merupakan hasil tangan manusia kreatif untuk diri sendiri maupun orang lain yang dibentuk berdasarkan inspirasi. Inspirasi itulah yang merupakan makna karya sastra yang diciptakan oleh manusia.

Mitos Agama:Bulan maulid adalah bulan yang baik untuk malaksanakan hajatan. Masyarakat Jawa selain kental akan budaya Jawa, mereka juga penganut terbesar agama Islam. Dalam agama Islam bulan Maulud atau Maulud Nabi adalah hari kelahiran Nabi Muhammad SAW. Di dalam bulan Maulud, dipercaya kebaikannya untuk melaksanakan hajatan, karena bulan Maulud adalah bulan kelahiran manusia sempurna yang membawa berkah dan keselamatan bagi seluruh umat manusia.

Syekh Amongraga (orang yang berilmu tinggi) setelah datang ke desa Wanamarta, desa ini menjadi hidup, tidak ada orang yang berjudi dan suara adzan terdengar bersahut-sahutan di setiap masjid. Oleh karena itu Memakan makanan, meminum minuman bekas orang yang berilmu tinggi dan berjabat tangan dengannya akan mendapat keberkahan dan rizki yang berlimpah.

Mitos sosial: Nasib manusia ditentukan berdasarkan keturunan. Misalnya jika orang tuanya seorang raja maka putrinya akan menjadi puteri.Orang tuanya seorang pembantu maka putrinya akan menjadi pembantu. Makna sebenarnya bahwa nasib sesuai dengan 
keturunan memang benar adanya, namun semua itu tergantung pada masingmasing individu. Jika anak raja dan kerajaannya hancur, maka pasti dia akan menjadi rakyat biasa walaupun kerajaan itu dihancurkan olehnya ataupun oleh orang lain. Sebaliknya, jika putri pembantu memiliki kegigihan yang kuat dalam mengejar cita-cita, maka dia bisa menjadi ratu dunia dengan usahanya melawan nasib dari orang tuanya. Karena nasib seseorang tidak akan berubah kecuali dia sendiri yang merubahnya.

Nilai Keutamaan Mitos Jawa Terhadap Mitos dalam Novel Centhini:40 Malam Mengintip Sang Pengantin.Mitos Jawa tidak dapat dipisahkan dari kehidupan bermasyarakat. Mitos dijadikan landasan dan pedoman kehidupan masyarakat Jawa.Setiap kegiatan mereka tidak lepas dari mitos yang melekat dalam diri manusia.Seperti Nasib manusia ditentukan berdasarkan keturunan. Misalnya, jika orang tuanya adalah seorang raja, maka putrinya akan menjadi seorang putri. Dan, jika orang tuanya seorang pembantu, maka putrinya akan menjadi pembantu.Mitos ini tidak dianggap sebagai sebuah mitos belaka, melainkan sudah menjadi kebenaran bagi masyarakat Jawa.

\section{SIMPULAN}

Mitos Jawa tidak dapat dipisahkan dari kehidupan bermasyarakat.Mitos dijadikan landasan dan pedoman kehidupan masyarakat Jawa.Setiap kegiatan mereka tidak lepas dari mitos yang melekat dalam diri manusia.Ritualritual tersebut dilakkukan masyarakat Jawa dengan penuh perhitungan matang, setiap acara bagi mereka ada ritual-ritual tertentu untuk keberkahan hidup.
Masyarakat menganggap dongeng adalah nyata, karena merupakan saringan dongeng, walaupun inti pesan telah luntur karena perubahan jaman.Seperti kisah rosul yang kebenarannya belum dapat dibuktikan, walaupun telah ada data dalam Al-Quran, tetapi masyarakat melakukan berbagai kegiatan hidup berdasarkan ajaran Rasul. Karena Rasul merupakan panutan dan pemimpin umat muslim. Sebagai mana yang telah diajarkan.Sehingga masyarakat bukan hanya menganggap kegiatan mereka seagai seuah mitos, namun sebagai kebenaran yang turun dari Tuhan.

\section{DAFTAR RUJUKAN}

Arikunto, Suharsimi. 2006. Prosedur Penelitian Suatu Pendekatan Praktik. Jakarta: PT Rineka Cipta.

Djajasudarma, Fatimah. Wacana.Bandung : Refika

Dojosantosa. 1989. Unsur Religius Dalam Sastra Jawa. Semarang:aneka Ilmu.

Endaraswara, Suwardi. 2003. Metodologi Penelitian astra.Yogyakarta:Pustaka Widyatama

Harahap, Muharrina. 2009. Mitologi jawa dalam novel-novel Kuntowijoyo. Universitas Sumatera Utara Medan.

Hutomo, Suripan Sadi. 1991. Mutiara Yang Terlupakan Pengantar Studi Sastra Lisan. Surabaya:HISKI.

Ratna, Nyoman Kutha. 2011. Antropologi Sastra. Yogyakarya: Pustaka Pelajar.

Wirodono, Sunardian. 2010. Centhini:40 Hari Mengintip Sang Pengantin. Jogjakarta:DIVA Press.

Zaidan, A. Rozak, dkk. 1997. Pusat Pengembangan dan Pembinaan Bahasa. Jakarta: Depatemen pendidikan dan Kebubayaan. 